IRSH 60 (2015), Special Issue, pp. I 8 5-205 doi:I0.1017/So0208590 I 5000462 (C) 2015 Internationaal Instituut voor Sociale Geschiedenis

\title{
Specialists, Spies, "Special Settlers", and Prisoners of War: Social Frictions in the Kuzbass (USSR),
}

\author{
I920-I950 \\ J U L I L A N D A \\ Buchenwald Memorial \\ 99427 Weimar-Buchenwald, Germany
}

E-mail: jlandau@buchenwald.de

\begin{abstract}
AвSTRACт: The Kuzbass coalmining region in western Siberia (Kuznetsk Basin) was explored, populated, and exploited under Stalin's rule. Struggling to offset a high labour turnover, the local state-run coal company enrolled deportees from other regions of Russia and Siberia, who were controlled by the secret police (OGPU). These workers shared a common experience in having been forcibly separated from their place of origin. At the same time, foreigners were recruited from abroad as experts and offered a privileged position. In the years of the Great Terror (1936-1938) both groups were persecuted, as they were regarded by the state as disloyal and suspicious. After the war, foreigners were recruited in large numbers as prisoners of war. Thus, migrants, foreigners, and deportees from other regions and countries constituted a significant part of the workforce in the Kuzbass, while their status constantly shifted due to economic needs and repressive politics.
\end{abstract}

From the beginning of the twentieth century, after the building of the TransSiberian Railway, the economic resources of Siberia became the subject of political consideration and planning efforts by the Russian and later the Soviet state. The Kuzbass region in western Siberia amazed Soviet planners with its vast supply of very high-quality coal - the layers of coal measuring

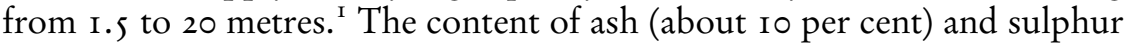
(between 0.4 and 0.7 per cent) was comparatively low. This enabled the production of coking coal, which in turn is indispensable for steel production. However, the climatic, infrastructural, and socio-geographic

I. The term Kuzbass - an abbreviation for Kuznetskii Bassein - describes a geographical depression of 26,000 sq. km north of the Altay mountains in the middle of the Eurasian continent and south-east of Novosibirsk and the Trans-Siberian Railway, at a distance of 4,000 km from Moscow. 


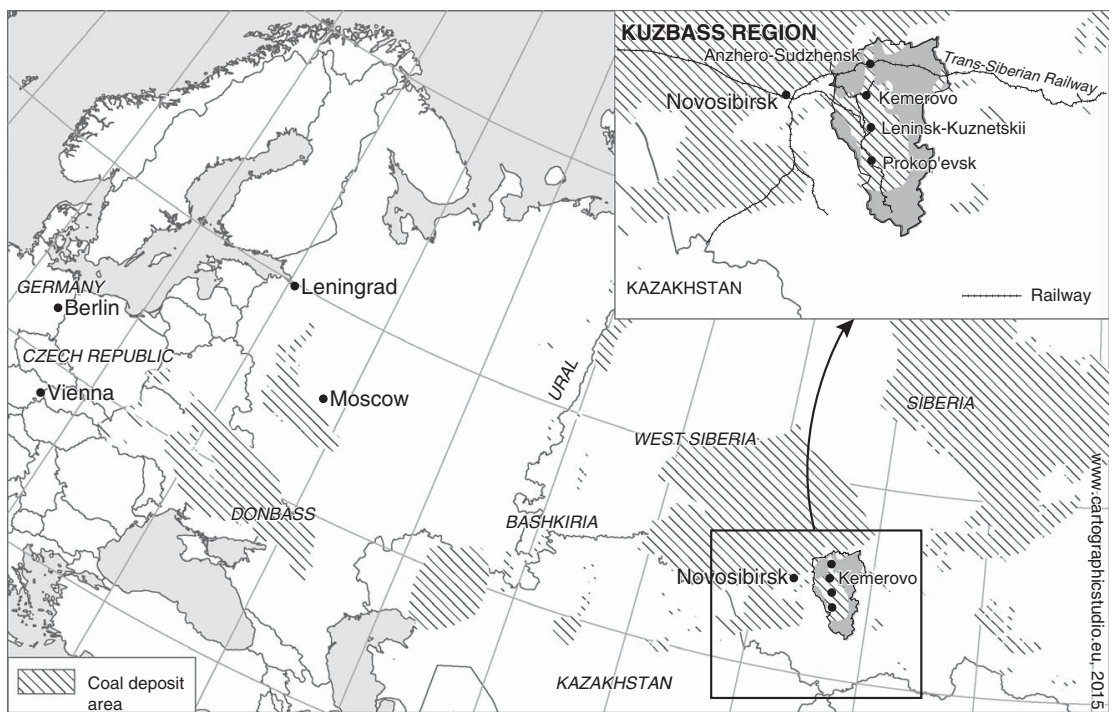

Figure I. The Kuzbass coalmining region in western Siberia and other coalfields in Russia and Ukraine.

conditions in the Kuzbass are extremely difficult. During the long winter months, lasting from the end of September until April, the climate is harsh, with extremely low temperatures. As the region was only sparsely populated, workers and technical experts had to be attracted from other regions as well as from other countries, while an infrastructure, including housing and technical facilities, had to be built at the same time.

In the years between the two world wars the Kuzbass region, with its coal, ore, and chemical resources, was intensively developed as part of Stalin's policy of forced industrialization. Huge numbers of workers were recruited, mobilized, and deported to provide the workforce needed to construct one of the biggest Soviet centres of coal production and heavy industry, deemed crucial for fuelling economic development under Stalin. ${ }^{2}$ The Kuzbass, located in an isolated place of strategic importance,

2. In recent years several regional and local studies have broadened our understanding of economic development under Stalin. The Kuzbass can be compared with other regions that were subject to Stalinist forced industrialization. See, for example, Stephen Kotkin, Magnetic Mountain: Stalinism as a Civilization (Berkeley, CA, I995); Tanja Penter, Koble für Stalin und Hitler. Arbeiten und Leben im Donbass I 929 bis 1953 (Essen, 2010); Anne D. Rassweiler, The Generation of Power: The History of Dneprostroi (New York [etc.], I998); and Klaus Gestwa, Die Stalinschen Großbauten des Kommunismus. Sowjetische Technik- und Umweltgeschichte, 1948-1967 (Munich, 2010). On the Kuzbass, see Kaleriia A. Zabolotskaia, Ugol'naia promyshlennost' [Coal Industry] (Kemerovo, I996); Liubov I. Gvozdkova, Stalinskie lageria na territorii Kuzbassa (30-40-e gg.) [Stalinist Camps in the Kuzbass in the I930s and 1940s] (Kemerovo, I994). 
became one of the two most important sites of heavy industry in the Soviet Union. ${ }^{3}$ During World War II, the Kuzbass was one of the main centres to which industries and workers from western parts of the Soviet Union were evacuated; after the war, requisitioned and deconstructed industries were brought to the Kuzbass, along with deportees and prisoners of war.

This article analyses the changing status and the perception of migrants of all kinds in the Stalinist economy of the Kuzbass before, during, and after World War II: new workers from the countryside, foreign experts ("specialists"), forced settlers, convicted forced labourers deported by the state's secret police and the People's Commissariat of the Interior (NKVD), ${ }^{4}$ as well as prisoners of war. During the decade before World War II - often labelled as the "war before the war" - complex mechanisms of segregation and disintegration were at work. Social, cultural, and ethnic distinctions became increasingly important and conflicts rose to unforeseeable levels. "Foreigners" and "migrants", originally hired as "foreign specialists", and young peasants, who were intended to form a new collective of workers, were suddenly identified as "foreign spies", "enemies of the people", and potentially disloyal kulaky (wealthy peasants and farmers who resisted forced collectivization). In the I940s, during the war with Germany and its allies, prisoners of war were employed coercively. In this article I will ask how policies of repression on the one hand, and the specific conditions facing developing heavy industry on the other, created differences that were connected to ethnic and cultural ascriptions, and affected everyday life in local society.

\section{SETTLING A WORKFORCE}

The first attempts to develop and exploit the vast stocks of Kuzbass coal date from the early i 920s, so before the First Five-Year Plan (1928-1932). Under the guidance of the Dutch communist Sebald Rutgers, British and

3. The other was Ukraine's Donetsk basin (Donbass). Some fundamental references on the latter can be found in Zoja G. Likholobova, "Der Bergmann in der Historiographie (1920-2000)", in Tanja Penter (ed.), Sowjetische Bergleute und Industriearbeiter - Neue Forschungen (Bochum, 2007), pp. I 5-29, I 5. On the industrialization of the Urals and Siberia, see Sergei A. Papkov and K. Teraiama (eds), Ural i Sibir' v stalinskoi politike [The Urals and Siberia in Stalinist Politics] (Novosibirsk, 2002).

4. On convict labour as a system of labour control in general, see Christian G. De Vito and Alex Lichtenstein, "Writing a Global History of Convict Labour", International Review of Social History, 58 (2013), pp. $285-325$. In the Soviet case, administrative and penal control was exerted by the NKVD, which took over economic and social functions, and had its own economic substructure. A range of different kinds of coerced labourers are described by the Soviet administrative term spetskontingent - a special contingent of coerced workforce at the disposal of the NKVD and forming a social stratum of its own. See Andrei B. Suslov, Spetskontingent v Permskoi oblasti: 1929-1953 gg. [Special Contingent in the Perm Region: 1929-1953] (Moscow, 2010). 
American communists, among them many "Wobblies" (International Workers of the World, IWW), founded a so-called Avtonomnaia Industrialnaia Kolonia [Autonomous Industry Colony, AIK], which tried to run mines, wood processing plants, and chemical industries in a unified organization.' Workers were recruited from the USA, Germany, and the Netherlands. In contrast to the egalitarian idea originally planned, foreigners held leading positions in production and enjoyed far better living and housing conditions. For the majority of the workers, living conditions were miserable. In the I920s, when the Kuzbass's urban population quintupled, ${ }^{6}$ workers lived in self-built zemlyanki, huts made of wood and clay, located partly in earth-holes. Sanitary conditions were appalling, with cesspits near water lines, a situation that caused endemic typhoid fever. ${ }^{7}$ Due to these difficult living conditions, only one-fifth of the foreign specialists originally attracted to the Kuzbass could be convinced to stay.

Many of the local workers successively recruited soon left their new workplace. As many as 6I per cent of workers did not return to work in February, most likely because of difficult climatic conditions, the lack of working garments, and the long distances from their huts to the workplace. ${ }^{8}$ The regional party committee believed miners often regarded their underground work as providing an auxiliary income to supplement their subsistence economy. Antagonisms between foreigners and local workers were frequently recorded during party meetings. The foreign leadership of the colony was perceived as a hostile takeover: "Why did you come, we got along well without you!", or: "Sir, when will you give us a caning?" Antagonisms were widespread also among the foreigners themselves: “Americans don't like the Dutch, the Dutch don't like the Germans, the latter don't like the Dutch - and we don't like any of them!"9

The colony was also not very successful in economic terms. Because of the lack of infrastructure, in particular railway lines, it was impossible to

5. For detailed studies on the "autonomous industry colony" experiment in Soviet Russia, see E. Krivosheeva, Bol'shoi Bill v Kuzbasse. Stranitsy internatsional'nykh sviazei [Big Bill in the Kuzbass: Aspects of International Relations] (Kemerovo, I990); and William T. Smith, The Kuzbas Colony, Soviet Russia, I92 I-I926 (Ann Arbor, MI, I979).

6. In I 920, 2,000 inhabitants lived in Prokop'evsk; by 1926 that figure had risen to almost I I,, 00 ; Julia Landau, Wir bauen den großen Kuzbass! Bergarbeiteralltag im Stalinismus 192 I-I94I (Stuttgart, 2012), p. 63.

7. Doklad o sanitarnom sostoianii Sibirskogo kraia [Report on the Sanitary Conditions in the Siberian Region], 1928, Gosudarstvennii Arkhiv Novosibirskoi Oblasti [Novosibirsk Region State Archive] [hereafter, GANO], R-47, op. I, d. 268, 1. I 2-25.

8. Stenogramma zasedaniia biuro Sibkraikoma VKP (b) 5.6.1926 goda. [Minutes of the Meeting of the Siberian Branch of the Russian Communist Party, 5 June 1926], Rossiiskii Gosudarstvennyi Arkhiv Sotsialno-politicheskoi istorii [Russian State Archive of Socio-Political History] [hereafter, RGASPI], f. 17, op. 67, d. 367, 1. 84 .

9. Doklad Kuznetskii okrugkom 8.1 i.1926 [Report of the Kuznetsk Regional Party Committee, 8 November 1926], RGASPI, f. I7, op. 67, d. 367, 1. 85 . 
transport the coal. With the monopolist state control of heavy industry established by the First Five-Year Plan in 1928, the "autonomous industry colony" experiment in the Kuzbass was closed down and transformed into the state-run monopolist Kuzbasugol' company. Foreign expertise, however, continued to play an important role into the i93os.

The First Five-Year Plan envisaged an enormous increase in annual coal production, from 2.4 million tons in 1928 to 10.5 million tons in 1932 . This plan was nearly fulfilled: in fact, almost 10 million tons were extracted in 1932. Production figures continued to rise rapidly, to I7 million tons in I937 and 21 million tons in I940. In summary, coal production increased tenfold between 1928 and I940. This development was far more rapid than in the Donbass, where overall coal output, having already reached 26 million tons in 1927, rose to 83 million tons in $1940 .{ }^{\circ}$ These achievements were enthusiastically used for propaganda purposes. "We build the big Kuzbass!", the title of a propaganda brochure by the head of the west Siberian party committee, was the main slogan of that time. With this propagandistic slogan, party officials hoped to promote a new local industrial identity in a sparsely populated, mostly agrarian region, trying to attract and integrate various migrants from other regions. ${ }^{\text {II }}$

The rapid increase in coal production was possible only because of the extensive exploitation of predominantly high layers of coal. The steep and unstable stratification of deeper layers, connected with the formation of gas, was much more challenging. Extensive exploitation was connected to extremely difficult working conditions. Living conditions remained poor as well, and did not improve with the successes in production. As a consequence, many of the newly recruited miners left after only one month. Most of the new miners came from the surrounding rural Siberian region; about 20 per cent were hired in the rural Volga region. As the newcomers could not be provided with housing space, working garments, or shoes, only a few of them could be deployed in the pits. Many of them returned home very soon, earning them the sobriquet "birds of passage".

Altogether, 40 per cent of all workers stayed for less than six months. ${ }^{{ }^{2}}$ In I 932 about 60,000 new workers were registered by Kuzbasugol', while at the same time 60,000 workers left the company. The overall total number of

IO. In Donbass, 83.2 million tons of coal were produced in 1940, about 52 per cent of total Soviet output; Kuzbass produced I 8.5 per cent of Soviet coal output; Likholobova, "Der Bergmann in der Historiographie”, p. I ; Landau, Wir bauen den großen Kuzbass!, pp. 74-75.

I I. For a similar development in the Donbass at that time, including propagandistic athletic competitions between the regions, see Tanja Penter, "Der 'neue sozialistische Donbass' und der Aufstieg des Bergmanns zur kulturellen Leitfigur", in idem, Sowjetische Bergleute und Industriearbeiter, pp. 79-95, 80.

I 2. A.S. Moskovskii, Rabochii klass Zapadnoi Sibiriv gody pervoi piatiletki [The Working Class in Western Siberia in the Years of the First Five-Year Plan] (Novosibirsk, 1964), p. 5 I. 
workers in any one month was about 32,000. Most migrants were peasants from rural western Siberia and Kazakhstan, who fled the 1932-1933 hunger crisis there, a consequence of collectivization and the state's requisitioning of entire grain harvests in agricultural areas. ${ }^{\mathrm{I}}{ }^{3} \mathrm{~A}$ workplace in the mining industry meant permission to reside in the town, as well as the allotment of ration cards, necessary for survival. The allotment of bread for miners was higher than for other workers, but it differed between regions of heavy industry. The Donbass was better off than other mining regions. ${ }^{14}$ In the Kuzbass, however, as the living conditions in the settlements around pits were extremely poor and working conditions very hard, many of the former farmers left their new workplace, searching for other opportunities in the European part of the Soviet Union.

\section{THE LOWEST RANK OF SOCIETY: DEPORTED $K U L A K Y$}

As the workforce of the pits changed every month, the fulfilment of production plans was constantly in danger. In this situation, the management of the pit took advantage of a contingent of forced labourers, provided by the secret police (OGPU), ${ }^{\text {I5 }}$ later reorganized as the Commissariat for Internal Affairs (NKVD). ${ }^{16}$ The leading party officials in western Siberia argued that with a deficit of 23,000 workers in the Kuzbass, it was necessary to engage detainees from the Siberian labour camps to be able to fulfil at least some of the economic plans. ${ }^{17}$ The plea was successful, but instead of labour camp detainees large numbers of people - so-called spetspereselentsy ("special settlers") - were deported directly from their place of origin to work in the mines. As early as spring 1930 the OGPU had started to provide forced labourers for the most difficult and work-intensive locations. ${ }^{18}$

The families were deported to their new place of work in chaotic circumstances. Neither the company nor the OGPU regarded themselves as

I3. In contrast to the massive famine in Ukraine in $1932-1933$ (which, in the notion of holodomor, is widely, though not undisputedly, characterized as a deliberate attempt at genocide), the famine in Russia and Kazakhstan has been investigated only marginally and is not part of the official record. According to newer accounts, more than I million people left the Kazakh ASSR in 1930-1932; only 500,000 of them returned. See Rudolf A. Mark, "Die Hungersnot in Kazachstan. Historiographische Aufarbeitung im Wandel”, Osteuropa, 54 (2004), pp. I I 2-I30, I 16.

I4. Penter, "Der 'neue sozialistische Donbass'", p. 80.

I5. Obedinennoe Gosudarstvennoe Politicheskoe Upravlenie, State Political Directorate; name of the Soviet secret police from 1922 to 1934 .

I6. Narodnyi Komissariat (Ministerstvo) Vnutrennikh Del, People’s Commissariat (Ministry from 1946) for Internal Affairs.

17. Griadinskii, Chairman of the Western Siberian Party Committee, to the Council of People's Commissars (SNK) RSFSR, 2 October 1930, GANO R-47, op. I, d. 749, 1. I60.

I 8. Postanovlenie SNK RSFSR 10.4.1930 [Resolution of the SNK, io April 1930], in Viktor P. Danilov and Sergei A. Krasil'nikov (eds), Spetspereselentsy Zapadnoi Sibiri 1930-vesna I 93 Ig. [Special Settlers in Western Siberia 1930 to Spring I93 I] (Novosibirsk, 1992), pp. 28-29. 
responsible for providing housing. The solution was to have the deportees build houses themselves, and in order to give them enough time before winter it was decided to start the deportations earlier in the following year, I93 I. It was not until July I93 I that conditions for the special settlers were regulated at a state level. Under the resolution passed at that time, the OGPU and the companies had to agree on the financing of the settlements: the companies were to pay 25 per cent of the wages directly to the OGPU for the costs of custody and administration. Special settlers and their families were not allowed to leave the settlements, which were guarded by the OGPU. Exceptions were made to allow children aged sixteen to be sent to other workplaces. Offences were punished by fines and detention of up to one month. ${ }^{19}$

Altogether, from I930 to I 932 about 23,630 kulak families, about 61,000 people, were brought to the Kuzbass from different regions of the Soviet Union. ${ }^{20}$ This forced relocation was part of the larger persecution of presumed wealthier farmers, the so-called kulaks, who resisted grain requisitioning and the collectivization of agriculture. Strikingly, about 40,000 families from western Siberia were sent, not to the nearby Kuzbass, but to camps in the Narymsk region of northern Siberia. At the same time, more than 50,000 special settlers were sent from the Moscow region and Bashkiria to the Kuzbass. ${ }^{2 I}$ Such relocations seem irrational, but we have to bear in mind that they were not primarily driven by economic motives; they were essentially political and punitive. While most male heads of the so-called kulak families were executed or interned in labour camps, the rest of the families were deported to special settlements, where they were meant to live and work in custody, but often without the working-age male members. ${ }^{22}$

19. Postanovlenie SNK ob ustroistve spetspereselentsev [Resolution of the SNK on the Settlement of Special Settlers], I July 193 I, in Viktor P. Danilov and Sergei A. Krasil'nikov (eds), Spetspereselentsy $v$ Zapadnoi Sibiri, Vesna I93I-nachalo 1933g. [Special Settlers in Western Siberia, from Spring I93 I to the beginning of I933] (Novosibirsk, I 994), pp. I4-I 5 . Therefore, the special settlers received - according to their ability to work - a nominal 75 per cent of their wages. The part of their wage paid directly to the OGPU was later reduced to s per cent; Landau, Wir bawen den großen Kuzbass!, p. I39; Afanas'ev et al. (eds), Istoriia Stalinskogo Gulaga. Spetspereselentsy v SSSR, vol. 5 [History of the Stalinist Gulag: Special Settlers in the SSSR, V] (Moscow, 2004), vvedenie [introduction], pp. 32-35.

20. Dokladnaya zapiska sekretarya Kemerovskogo obkoma KPSS M.I. Guseva L.P. Berija [Note from the Secretary of the Kemerovo Party Committee to L.P. Beria], 20 May 1953, in Gosudarstvennyi arkhiv Kemerovskoi oblasti [State Archive of Kemerovo Region] (ed.), Neizvestnyi Kuzbass [Unknown Kuzbass], vyp. I (Kemerovo, I993), pp. 29-30.

2 I. Sergei A. Krasil'nikov and V.V. Sarnova, "Deportatsia”, Entsiklopediia Sibiri ["Deportation”, Encyclopaedia of Siberia], http://russiasib.ru/deportaciya/, last accessed 29 July 2015 .

22. This "archipelago" of special settlers was almost unknown for a long time and their history was less developed than that of the Gulag detainees. Large-scale experience with special settlers working in difficult and distant workplaces preceded the exploitation of Gulag detainees for all branches of industry. See Lynne Viola, The Unknown Gulag: The Lost World of Stalin's Special 
In terms of economic aims, to exact labour from those who had newly arrived was thus highly inefficient - though the work norm was set in some places twice as high as for the free workers. ${ }^{23}$ Also, due to neglect during and after deportation, many of the special settlers were unable to work at all. In August 193 I, only 26 per cent of the special settlers in Prokop'evsk were deemed fit enough to work - the others were fit only for repairing shoes, weaving baskets, or repairing tools. ${ }^{24}$ Because of insufficient food, housing and medical support, 8-I 2 per cent of the children under three years of age died. ${ }^{25}$

Kuzbasugol' intervened in the repressive policies of the OGPU, demanding deportations of young males only, and implementing economic stimuli, including offering release from forced settlement and a partial rehabilitation in exchange for fulfilling the high work targets. Although in most cases these promises were not fulfilled, many of the younger special settlers were among the most productive, even affiliating themselves with the Stalinist values of social hierarchy. Also, the regime offered these younger detainees certain opportunities for advancement. The Central Party Committee decided in December 1935 that young special settlers would be allowed to graduate in polytechnic institutes, though only at a medium level. ${ }^{26}$ For educational purposes they were allowed to leave their forced settlements for a short time. As Gulag officials noted approvingly, this parttime separation alienated them from their mostly "anti-Sovietic" parents. ${ }^{27}$

In addition to the Gulag prisoners and the special settlers mentioned above, further contingents of forced labourers arrived in the following

Settlements (Oxford, 2007); and Sergei A. Krasil'nikov, Serp i Molokh. Krest'ianskaia ssylka v Zapadnoi Sibiriv 1930-e gody [Sickle and Moloch: Deportation of Peasants in Western Siberia in the 1930s] (Moscow, 2003).

23. The OGPU criticized the irregular high-work norms and appealed to local OGPU representatives to equal them. See Tsirkularnoe pis'mo OGPU, 2 I.7.193 I [OGPU circular], 2 I July I93 I, in Danilov and Krasil'nikov, Spetspereselentsy v Zapadnoi Sibiri, Vesna I 93 I-nachalo I 933 g. pp. $53-56,54$.

24. In fact, only I 6 per cent of the special settlers in Prokop'evsk were actually sent to work, as the OGPU noticed. See Spetssvodka PP OGPU v Krajispolkom, 2 I.8.193 I [Special OGPU report to the West Siberian Central Executive Committee], 2 I August I93 I, in Danilov and Krasil'nikov, Spetspereselentsy $v$ Zapadnoi Sibiri, Vesna I93 I-nachalo I933g. pp. I46-I I I, I46-I47. See also note 20 on pp. 3I $4-3$ I 5 .

25. Informatsia OGPU v TsKK VKP (b), Janvar' 1932 [OGPU report to the Central Control Commission of the Soviet Communist Party], January 1932, in Danilov and Krasil'nikov, Spetspereselentsy $v$ Zapadnoi Sibiri, Vesna I93 I-nachalo 1933g. pp. 76-84, 8 I.

26. Postanovlenie SNK i TsK VKP (b) no. 2663, I 5.I 2.1935 [Resolution of the SNK and the Central Comittee of the Soviet Communist Party], is December 1935, cited in Afanas'ev et al., Istoriia Stalinskogo Gulaga. Spetspereselentsy, p. 74I, n. 86. See Landau, Wir bauen den großen Kuzbass!, p. 339.

27. Doklad nachalnika GULaga I.I. Plinera narkomu vnutrennykh del SSSR N.I. Ezhovu o sostoianii trudovykh poselkov NKVD na I sentiabria 1936g. [Report by the Director of the Gulag I.I. Pliner to Commissar N.I. Ezhov], 3 I October 1936, in Afanas'ev et al., Istoriia Stalinskogo Gulaga. Spetspereselentsy, pp. 227-235, 234. 
years: those deported after 1939 because of their "suspect" nationality (ethnic Germans, for example), and in the late I940s prisoners of war and internees from Germany and Japan. Being subordinated to the NKVD as well, these groups are included in the contemporary term spetskontingent. They were constricted and discriminated against in various ways. At several Kuzbasugol' mines they comprised between 25 and 40 per cent of the workforce. ${ }^{28}$ Repressive measures were taken to dissolve any familiar or ethnic boundaries and loyalties, thereby creating, by administrative means, a new and dependent social group.

\section{THE HIGHER RANKS OF SOCIETY: FOREIGN SPECIALISTS}

\section{IN THE 1930 s}

In the early I930s, foreign mining and engineering specialists were again recruited from abroad, but with decisive differences compared with the recruitment of foreign specialists for the "autonomous industry colony" in the I920s. Now the focus of the recruitments changed: foreigners - mostly German, Austrian, and Czech engineers and miners - were recruited, not because of their communist background and their willingness to support the construction of the Soviet Union, but strictly because of their expertise. Foreign specialists were deployed to operate special, newly imported machines. Contrary to their professional ethics and habits, a miner was engaged not as a general specialist for complex and different challenges in underground mining, but as an isolated specialist for complex machinery, for example the newly imported coal-cutting machine. This nexus was advantageous on the one hand, as it allowed these foreign specialists to negotiate higher wages in accordance with their "special" profession. On the other hand, it exposed the specialists and made them vulnerable, as they could be made responsible for the functioning - or non-functioning - of these imported and costly machines.

Campaigns organized by newly established offices in the Soviet trade missions in Berlin and Vienna promised high wages to mining engineers, including payments in foreign currency, while ordinary foreign workers received just one-fifth of their wages and were provided only with single rooms in residential accommodation instead of apartments. ${ }^{29}$ Many skilled workers therefore tried to get acknowledged as "specialists" in order to

28. Doklad o peredache khoziaistvennoi deiatel'nosti UNKVD [Report on the Economic Activity of the UNKVD], 8 February 1938, Gosudarstvennyi Arkhiv Rossiiskoi Federatsii [Russian Federation State Archive] [hereafter, GARF], f. 94I 4, op. I, d. 5, 1. 8-9, 3 I.

29. Osnovnye usloviia priglasheniia v SSSR inostrannykh rabochikh [Conditions of Invitation of Foreign Workers to the SSSR], i6 February I93 I, Gosudarstvennyi Arkhiv Kemerovskoi Oblasti [Kemerovo Region State Archive] [hereafter, GAKO], f. R-I 77, op. 3, d. 9, 1. 87. I am grateful to Dr Elena Kuznetsova, Kemerovo, for introducing me to this collection of documents in the Kemerovo Region State Archive. 
negotiate better contracts..$^{30}$ As a result of these recruitment policies abroad, about I, 500 foreign specialists and workers moved to the Kuzbass between I93 I and I938. As Kuzbasugol' was unable to guarantee the terms and conditions of the contracts, many of these workers left after a short time, a matter of major concern to the local trade-union administrations, as well as to the Politburo in Moscow. Disillusioned returnees posed enormous problems for foreign propaganda. While the narrative of Soviet propaganda was one of economic expansion in line with the First Five-Year Plan as a counterstatement to the world economic crisis, the returnees told a different story. "At home in Germany even the unemployed live in better conditions than workers here in the Soviet Union", a German coal hewer was cited as reporting. ${ }^{3 \mathrm{I}}$

Local trade unions worried especially about the wives of foreigners. Foreign women, not knowing any Russian and selling eggs on the black market, were perceived as loafers who demoralized their husbands. ${ }^{32}$ In reality, however, they acclimatized very quickly to the omnipresent deficits and managed to supply themselves and their families with food during the famine.

Most of the foreign workers returned home. In I937, there were only I 26 foreigners left in the Kuzbass, among them communists and Jewish workers seeking refuge from National Socialist persecution. The returning workers and engineers were closely interviewed by the German Political Police (Gestapo) in order to extract first-hand material for anti-communist propaganda. Given their original purpose, these interviews have to be treated critically, but they nevertheless give valuable insights into the conditions of local society in the Kuzbass. The dwellings of the Russian workers were "fumy and damp", one German hewer recorded after his return:

There were no separate spaces; the whole family lived in one room, which was bedroom, living room, and kitchen in one. No German worker would have lived in such a room for one day, let alone for the long Siberian winter. The Russian worker was as primitive as his accommodation. There was no light and water for these self-constructed dwellings. ${ }^{33}$

30. Walter Szevera, "Österreichische Facharbeiteremigration in den zoer Jahren in die Sowjetunion", in Barry McLoughlin, Hans Schafranek, and Walter Szevera, Aufbruch, Hoffnung, Endstation. Österreicherinnen und Österreicher in der Sowjetunion 1925-1945 (Vienna, 1997), pp. 7I-I 58,96 , and 98.

3 I. Kharakteristika Lidtke Ernst (=Ernst Lüdtke), GARF, f. 545 I, op. I3a, d. 465 , 1. 9. "Kharakteristika" was a personnel assessment of a member of the union, written by other members and without his or her approval. These assessments could serve as evidence for presumed political misconduct.

32. Stenogramma soveshchaniia inorabochikh i spetsialistov pri TsK Soiuza ugol'shchikov [Minutes of the Meeting of Foreign Workers and Specialists at the Central Committee of the Miners' Union], GARF, f. 7416, op. I, d. I 50, 1. I I 4.

33. Vernehmung August Dreyer, 5 November 1937, Politisches Archiv des Auswärtigen Amtes [hereafter, PA AA] R I04553A. 
On the one hand, these statements show the influence of National Socialist propaganda, deducing habits and living conditions from an essentially "national" character. On the other hand, these observations can complement official Soviet documents, which speak of barrack rooms allotted to foreign workers but scarcely mention that special settlers were left on their own to build simple earthen caves instead of houses: "In the coalmine areas, where I was working, the workers lived in primitive earthen caves and simple wooden barracks. One can see these earthen caves along each road; they even form quarters in the town. They consist of dirt and mud." 34

Inadequate infrastructure and housing caused a distinct hierarchy among the poor. The allocation of living space was an exclusive process, in which only a few were privileged enough to live in houses, even fewer in houses built of stone, while many had to live on their own, in self-dug earthen caves.

\section{ACCIDENTS AND GROWING DISCONTENT}

The "hierarchy of the poor", constitutive for local society in the Kuzbass in the I930s, was apparent in many ways: differential forms of housing and different access to goods marked one's position in local society. ${ }^{35}$ The common experience of omnipresent deficits and shortages, together with the openly visible privilege of a few, was dangerous and caused a potentially unstable situation. But open conflicts began to surface only against the background of the extremely dangerous underground working conditions. Different rock formations and steeply sloping layers of gaseous coal tending to self-ignition represented enormous problems for engineers and workers in the Kuzbass pits. In summer I93 I a gas explosion in Kemerovo and an underground fire in Prokopyevsk left six people dead and nine badly injured. ${ }^{36}$

Success in increasing coal production could not be achieved without cost, and it was the workers who paid the price. Leading engineers were aware of this and discussed the problem of how to increase production in line with economic plans without endangering the workers, a problem that they were

34. Vernehmung Wilhelm Bednarz [Interrogation Wilhelm Bednarz], 3 November 1937, PA AA R 1045564 .

35. Elena Osokina, Za fasadom "Stalinskogo izobiliia". Raspredelenie i rynok v snabzhenii naseleniia $v$ gody industrializatsii, 1927-I94I [Behind the Face of "Stalinist Abundance": The Role of Distribution and Markets for the Supply of Soviet Public during Industrialization, 1927I94 I] (Moscow, I 998), p. I 26; [edited English version: Our Daily Bread: Socialist Distribution and the Art of Survival in Stalin's Russia, I927-194I (New York [etc.], 200I)].

36. Protokol zasedaniia komissii ZapSibKraiispolkoma ot 17.6.193 I po obsledovaniiu proisshedshego vzryva [Protocol of the Meeting of the Commission of the Western Siberian Executive Committee Investigating the Gas Explosion, I7 June I93 I], GARF, f. 74 I6, op. I, d. 70, 1. 54-56. 
ultimately unable to resolve. Until I93 I coal was extracted in higher beds and extracted cavities could be worked using the block-caving method. At deeper layers and for thicker seams, it was necessary to use backfilling technologies. As only 40 per cent of the wood necessary was to hand, the existing wood often being wet and difficult to work, pillars of coal were left in the field. Apart from the economic loss this represented, since it entailed leaving up to between 40 and 60 per cent of the coal in the goaf (that part of a mine from which the coal has been partially removed), this method was dangerous as it caused the evolution and spontaneous ignition of gas. ${ }^{37}$

As early as 1933, the leading engineers had to cope with an increasing number of underground fires. A special ministerial commission investigated the situation in the Kuzbass mines and demanded that the mines use only backfill, for which clay should be used since it was a cheaper building material. But in spite of this explicit order, a separate decision was made for some shafts in Prokopyevsk containing high-quality coking coal. During a "transitional period" the miners were required to use the block-caving method, as coking coal was urgently needed for steel production in the Urals. ${ }^{38}$ Not surprisingly, the number of accidents sharply increased during pre-war years. In I93 I almost 6,000 accidents were reported, in 1936 more than 20,000 . Most of these accidents occurred because of falling rocks, coal, and fragments. The death rate was almost constant over the years (2.5 per I,000 workers from I 932 to I936), but the increasing number of accidents was alarming. ${ }^{39}$

Contemporaries held the Stakhanov movement, which began in 1935, responsible for the increasing number of accidents and the damage to machines. After Aleksei Stakhanov, who was well prepared and supported by the local party committee, had set a record in extracting coal, the campaign was rolled out across the USSR, with individual production records being rewarded in all branches. The campaign promoted the Stakhanovtsy workers as the new elite among workers. They prided themselves on having accomplished a complete personal transformation. Having been illiterate shepherds or small farmers in the past, these workers had managed to train themselves to the level of skilled miners and were now able to work with

37. Zhavoronkova, Istoriya sistem razrabotki moshchnykh krutopadayushchikh ugol'nykh plastov Prokop'evsko-Kiselevskogo mestorozhdeniya Kuzbassa (1917-1948) [The History of Working on Steep Seams in the Prokop'evsk-Kiselevsk Seam in the Kuzbass (I917-I948)], Trudy po istorii Tekhniki. Materialy pervogo soveshchaniya po istorii tekhniki [Works on the History of Technology: Proceedings of the First Convention on History of Technology] (Moscow, 1954), pp. $17-47,29$.

38. Protokol zasedaniia komissii NKTP po sistemam razrabotok [Protocol of the Meeting of the Commission in the People's Commissariat of Heavy Industry on Caving Systems], 6 March 1933. Rossiiskii gosudarstvennyi Arkhiv Ekonomiki [Russian State Archive of the Economy] [hereafter, RGAE], f. 7566, d. I25, l. 6-9.

39. GARF, f. 7416, op. I, d. I87, S. 75 ; RGAE, f. 7566, op. I, d. I98 I, 1. 59. 
new and difficult machines. They were privileged in many ways. They got better accommodation, clothing, and medical care, and ate their meals in special canteens. Within the company, however, neither the authorities nor the co-workers liked the Stakhanov workers, as they challenged the fragile relationship and unexpressed agreement between workers and directors: to keep production at a level that would not evoke increasing demands from the central authorities. They thus faced open hostility. For instance, as the local trade union recorded, one Stakhanov worker was screamed at, pilloried, and robbed at the market. ${ }^{\circ}$

At the same time, antagonisms between leading personnel and individual workers increased in general. Several sources tell us about the growing discontent among workers. Party records, for instance, include a report about workers who, after repeating the official slogans of "critique and selfcritique", went on to criticize low safety levels at work, the lack of garments for workers, and defective machines. This criticism was voiced despite worker awareness that they could be punished for openly questioning government measures. As German returnees reported, not only was discontent growing, fear was pervasive. ${ }^{4 \mathrm{I}}$

\section{CHANGING PERCEPTIONS: "FOREIGN SPIES" AND “ENEMIES OF THE PEOPLE”}

On 22 September 1936 a build up of methane gas exploded in Kemerovo's Central Mine. Ten miners died and fifteen were severely injured. Although the accident was nothing new after an increasing number of explosions and fires in the previous two years, local and central officials used it to start a campaign to have the alleged culprits tried and convicted, thus shifting the blame to a number of exposed persons in order to direct possible discontent in directions less perilous for the regime. Although the social dimensions of Stalinist society have been studied very thoroughly, ${ }^{42}$ few attempts have been made to analyse the impact of mass repressions in their interdependence with specific environmental and labour conditions. ${ }^{43}$ The impact of the Stalinist terror on mining seems to have been of

40. Stenogramma zasedaniya Zapsibkraikoma [Minutes of the Western Siberian Party Committee], GANO, f. R-i i I5, op. 2, d. 7, 1. 27.

41. See Landau, Wir bauen den großen Kuzbass!, pp. 31 3-3 17, for further references.

42. See, among others, the work of Sheila Fitzpatrick, Anne D. Rassweiler, David R. Shearer, Moshe Lewin, Melanie Ilich, Wendy Z. Goldman, Roberta Manning, Arch Getty/Oleg Naumov, Viktor I. Isaev, Sergei A. Krasil'nikov, Sergei A. Papkov, Oleg Khlevniuk, and Gabór T. Rittersporn.

43. See, for the years 1948-1967, Klaus Gestwa, Die Stalinschen Großbanten des Kommunismus. Sowjetische Technik- und Umweltgeschichte 1948-1967 (Munich, 2010). Rittersporn's assessment from the early i 990 s remains, in my view, valid even today: Gabór T. Rittersporn, "The Omnipresent Conspiracy: On Soviet Imagery of Politics and Social Relations in the 1930s", in 
particular importance, as the mining industry played a key role in Stalinist industrialization propaganda. The miner was a propagandistic hero and it was therefore no coincidence that the hewer Stakhanov became the figurehead of the movement named after him.

Directly after the explosion in Kemerovo, local party and NKVD officials established an investigative commission. However, it was deemed less important to find the reasons for the accidents than to allocate blame. Before the investigation had even been completed, the NKVD arrested leading engineers and the head of the mine administration. ${ }^{44}$ The Kemerovo explosion coincided with another important turn in the politics of Soviet repression. Four days later, on 26 September 1936, the People's Commissar of the Interior, Genrikh Jagoda, was arrested and replaced by Nikolai Ezhov. The following show trials investigating the Kemerovo accidents marked the beginning of the "Great Terror" of $1936-1938$.

A show trial in Novosibirsk was prepared, taking place in November 1936. Among the leading engineers arrested and convicted was the German engineer Emil Stickling, who was accused of preparing a fascist coup d'état together with Russian engineers. Other engineers arrested were to be heard as "witnesses", after being manipulated into giving evidence under torture. One of them was Mikhail S. Stroilov, who had been involved in the recruitment of foreign specialists in the Ruhr and had only recently, in I935, been awarded the Orden Lenina for his mining inventions. The accusations of "contacts with foreigners" and "foreign expertise" played an important role during the trial in Novosibirsk and in the following trial in Moscow in January 1937.

In Novosibirsk, the process was held partly in secret. Stickling was interrogated in a secret session, where he admitted the accusations against him after being threatened that his Russian wife would be executed. Finally, in the Novosibirsk trial the nine defendants were found guilty and sentenced to death. The sentence was proclaimed before a selected public audience and the event already had all the hallmarks of the show trials to come. Later, three of the defendants, among them Stickling, were amnestied and the death penalty was commuted to imprisonment.

The Novosibirsk trial was followed by another, larger show trial in Moscow, which adjudicated on several problems in all branches of heavy industry. The main accused were Georgy Pyatakov - the Deputy People's Commissar for Heavy Industry - and Karl Radek, former leader of the KPSU's international bureau. From the Kuzbass, the local leading engineers

Arch Getty and Roberta Manning (eds), Stalinist Terror: New Perspectives (Cambridge, 1993), pp. 99-II 5 , I00.

44. On these events see Sergei Papkov, Stalinskii Terror v Sibiri, 1928-I94I [Stalinist Terror in Siberia, I928-1941] (Novosibirsk, I997), p. I62. 
were on trial. According to the accusations, a group of alleged conspirators in the Kuzbass had been instructed by Trotsky, together with German and Japanese spies, to induce fires and explosions in the mines. The local Kuzbass newspaper reported extensively on the trials. In addition to the trial documentation, the newspapers printed letters to the editor in which "the workers" allegedly demanded a thorough investigation of what they saw as the murder of ten miners in Kemerovo and "merciless punishment" for the "villains". 45 These letters - though collectively written by workers under the watchful eye of the party committee at their place of work produced a direct connection between the process in the capital and the events in the Kuzbass.

The accused were sentenced to death or to long prison sentences (though those sent to prison were also later shot)..$^{46}$ The trials were documented in propaganda brochures and longer accounts in Russian and other languages. In these propagandistic accounts, "spies" and "agents" played a central role, being directed by foreign powers to fight against the Soviet Union from within. Indeed, during the pre-war years, the Soviet Union was on a permanent state of military alert - which was not completely unjustified given Hitler's accession to power, the civil war in Spain, Italy's invasion of Ethiopia, and the German remilitarization of the Rhineland. The explosions and fires in the mines seemed to prove specifically, and onsite, the existence of a "Fifth Column". ${ }^{47}$ At the same time, this intimidation enabled the mining society to retain its own, distinct rules and to keep the potential for unrest and solidarity under control.

The resonance of the Kemerovo trial on mining "wreckers" and its importance for Soviet international propaganda is illustrated by a brochure written by the émigré Austrian communist and author Ernst Fischer and published by Workers' Library Publishers in New York in 1937. The author, working as a journalist for the Communist International (Comintern), depicted the international "Trotskyite wreckers" in the Kuzbass (Figure 2). A year later he emigrated to Moscow, where his wife, Ruth von Mayenburg, claimed that he was himself in danger. ${ }^{48}$

In the following years, the repressions against leading personnel and foreigners in the mines continued. After 1938 , over 70 per cent of leading personnel were either arrested or executed. ${ }^{49}$ By 1937, only 43 of the 1,000

45. Kuzbass [local daily newspaper], 22 January 1937.

46. Kaleriia A. Zabolotskaia, "Oni zhili v Kemerovo i sozdavali bol'shoi Kuzbass” [They Lived in Kemerovo and Built the Big Kuzbass] (Kemerovo, 1998), pp. 70-73, 72.

47. Roberta T. Manning, "The Soviet Economic Crisis of $1936-1940$ and the Great Purges", in Getty and Manning, Stalinist Terror, pp. I 16-I4I, I 36.

48. Ruth von Mayenburg, Hotel Lux, Das Absteigequartier der Weltrevolution (Munich, I99I [1978]), p. 202.

49. Kaleriia A. Zabolockaia, Ugol'naia promyshlennost' [Coal Industry] (Kemerovo, 1996), p. is8. 


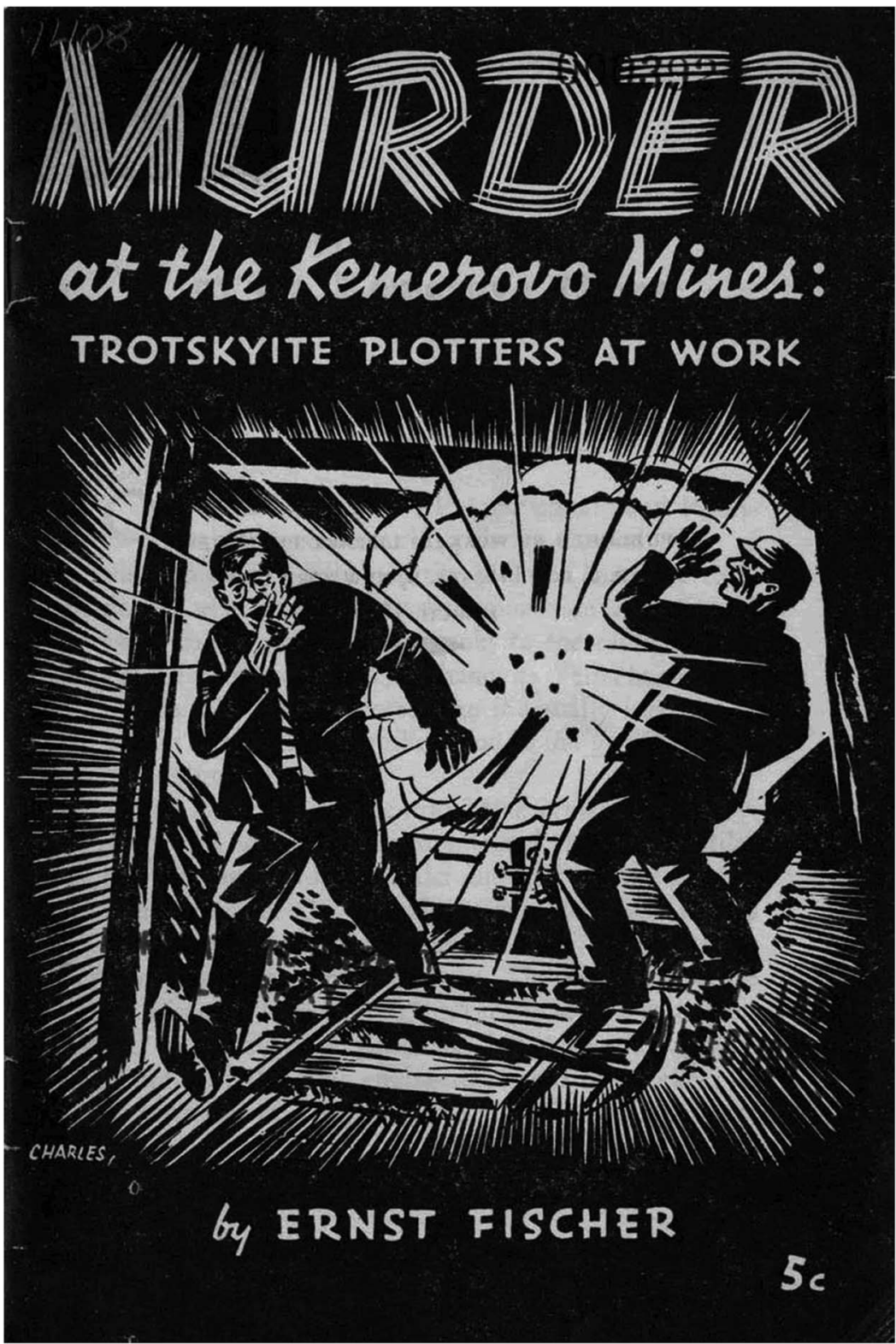

Figure 2. Woodcut illustration of the Kemerovo mining accident, September 1936. The miner on the left represents the elder "Trotskyite" spy, getting himself out of danger, while the worker on the right is caught by the explosion.

Cover of the brochure Murder at the Kemerovo Mines: Trotskyite Plotters at Work, by Ernst Fischer (New York, 1937). A digital copy is available at Florida Atlantic University Digital Library: http://fau.digital.flvc.org/islandora/object/fau\%3 A4432; last accessed 20 Angust 2015. 
foreigners working in the Kuzbass in 1932 were left. However, these years saw not only the complete replacement of the elite workers in the mines, but also significant technological advances. Now, backfilling technologies and safety protection facilities, such as iron plates, became more important..$^{\circ}$ The catastrophes of the early i93os seemed to have been overcome, and the number of accidents decreased until the beginning of the r 940 .

A second wave of Stalinist repression in the Kuzbass was directed against the special settlers. Starting in summer 1937 and continuing until 1938 , the NKVD arrested thousands of special settlers - who were still highly marginalized despite the restricted freedoms they had been given in exchange for good production results (concessions that did not, of course, include freedom of movement). But even after submitting to the goals of the authorities, the special settlers continued to be seen as potentially disloyal. In June I 937 the local head of the party committee, Robert I. Ejche, reported to the CPSU's Central Committee concerning the successful arrest of a group of over 20,000 alleged conspirators accused of acting on behalf of German and Japanese agents. ${ }^{51}$

This formed part of the major campaigns during the years of the "Great Terror", in which thousands of people were arrested and executed on NKVD orders directed against former kulaky and "anti-Soviet elements" (in summer 1937) as well as against "national minorities" (during 1938). In these orders, quotas defined the number of people in every region who had to be deported or executed; local NKVD officials asked the central authorities for permission to raise these quotas and were given approval to do so. Kulaky of Soviet-German origin were seen as especially dangerous, as they were alleged to have contacts with German specialists. Thus, the SovietGerman special settlers were accused of forming the rank and file of a fascist movement in Russia, with the German specialists cast as their leaders.

\section{PRISONERS OF WAR}

After the German attack on the Soviet Union, the system of different camps and colonies expanded, organized by the POW administration of the Commissariat of the Interior (Glavnoe Upravlenie Voennykh i Internirovannykh) [GUPVI]). Kuzbasugol' called for new camps near the mines to keep the workforce at the necessary level, as young men had been

50. Landau, Wir bauen den großen Kuzbass!, p. 299.

51. Tezisy doklada N.I. Yezhova na iiunskom plenume TsK VKP (b), 22.6.1937 [Theses of the Speech by N.I. Yezhov at the June Plenum of the Central Committee of the All-Russian Communist Party, 22 June 1937], in Viktor Danilov et al. (eds), Tragediia sovetskoi derevni. Kollektivizatsiia $i$ raskulachivanie. 1927-1939: Dokumenty i materialy, Vol. 5, 1934-36 [The Tragedy of the Soviet Village: Collectivization and "De-Kulakization", 1927-1939] (Moscow, 2002), pp. 306-308. 
recruited for the Red Army. The first group to be interned in the camps were "mobilized soldiers of the workers" army", men and women of Soviet-German origin, who were supposed to be collectively disloyal to the Soviet state. In 1942 special camps were built around the pits and extended the following year. Later, once the war had finally ended, leaving a country totally devastated and depopulated, more than 26,000 prisoners of war and internees, men and women, among them Germans, Polish, Japanese, Chinese, Austrian, Slovakians, and Ukrainians, were sent to the Kuzbass. About 60 per cent of them were assigned to work in the mines. ${ }^{52}$

After their arrival in the Kuzbass, the prisoners of war and internees were divided into different groups, according to their health status. As it turned out, many were unable to work due to malnutrition and the epidemic diseases that had spread during their long journeys. Also, the camps were not prepared for the high number of new internees and were therefore unable to provide food, housing, clothes, and shoes. For example, only 60 per cent of the internees in Camp No. 525 near Kemerovo could be put to work - even after the Deputy Commissar of Mining, Egor T. Abakumov, had announced to the director of the Kemerovo coalmines in 1944: "We have to exploit the workers that the state is giving to us maximally and to the full". ${ }^{3}$ But as most POWs were increasingly failing to meet their work targets, with rates dropping from 50 per cent to only ro per cent, the managers knew that they had to give POW workers some time to recover in order to meet production plans. In the devastated country, the food supply was catastrophic, decreasing dramatically in winter I945 and becoming even worse in 1946. Only one-half of the POWs were able to work in I946. As their food ration depended on work targets being met, those unable to work were in a desperate situation. In the face of this, and constantly decreasing supplies by the state, the camp administration at last deployed some prisoners to procure food, by fishing or collecting mushrooms and herbs for example.

As the number of prisoners and internees able to work in the pits remained low, they were replaced by internees from the so-called special camps in Germany, where people had been interned because of their prior role in the Nazi administration or propaganda apparatus, or simply because they were assumed to be potentially dangerous. Contrary to official announcements,

52. Nina M. Markdorf-Sergeeva and Rashid S. Bikmetov, "Soderzhanie i trudovoe ispol'zovanie inostrannykh voennoplennykh v Kuzbasse" [Position of Foreign Prisoners of War and their Exploitation to Work in the Kuzbass], in Nina M. Markdorf-Sergeeva and Rashid S. Bikmetov (eds), Inostrannye voennoplennye v Kuzbasse v I940-e gody. Dokumenty $i$ materialy [Foreign Prisoners of War in the Kuzbass in the I940s: Documents and Materials] (Kemerovo, 2002), pp. I I-63, I 8 .

53. GAKO, f. P-75, op. I, d. i s , 1. 7-8, cited by Markdorf-Sergeeva and Bikmetov, Soderzhanie $i$ trudovoe ispol'zovanie, p. I6. 
which spoke of 8,500 internees to be sent to the Kuzbass, actually only 5,332 were sent to the Kuzbass and the Karaganda basin in Kazakhstan in I947. Food supplies had been catastrophic also in the Soviet occupation zone in Germany, especially in winter 1946-1947. The internees in the Soviet special camps were to receive only 300 grams of bread per day, the food ration of a "non-working" person, and one-third of the internees died in the special camps in Germany's Soviet zone. It is thus not surprising that the commission in charge of choosing possible workers in the camps found that only a small proportion were healthy enough to be sent to the Soviet Union for work. ${ }^{54}$

After 1947, the situation improved. As many workers in poor health were repatriated, Kuzbasugol' helped the remaining workers with higher food rations and improved dwellings - but only to those deployed in the coal industry, and always strictly according to profession, workplace, and nationality. Under the new regulations, a hewer would receive one kilo of bread per day, other underground miners only 900 grams. However, a Japanese hewer was allotted only 750 grams of bread per day. ${ }^{55}$ Due to better food provisions and health care, the situation further improved in I948. Now almost 90 per cent of prisoners were designated "able to work".

Also, the status of a prisoner of war improved fundamentally. They were now employed according to their professions, which enabled them to earn a premium. However, wages were not paid in cash. After a deduction of 35 per cent to pay for the maintenance of the camp, their wages were credited to personal accounts at special stores in the camps, where they were able to buy tobacco, clothes, and other products. These "luxury goods" - and in the context of the postwar misery in Soviet Russia these products were indeed luxurious - were an indication of their improved social status. Also, their confinement was eased, not least because guards, usually former soldiers, increasingly refused to accept the authority of the camp administration and did not leave their barracks, which were far away from the POW camps. Guards now consisted of other POWs, who were equipped with whistles and white armlets. At some camps, the gate was left open during the day. Around it, the locals often traded with the POWs, who sold self-made pocket knives, lighters, pencils, and medals. While control was thus shifted to the POWs themselves, denunciations were rewarded by the

54. Beschluss des Ministerrates Nr. 2728-I I 24ss "Zum Abtransport von in Gefängnissen und Lagern inhaftierten Deutschen aus Deutschland" [Decision of the Council of Ministers No. 2728-I I 24ss "On the Deportation of Interned Germans from Prisons and Camps in Germany"], in Sergej Mironenko, Lutz Niethammer, and Alexander von Plato (eds), Sowjetische Speziallager in Deutschland 1945-1950, Bd. II: Sowjetische Dokumente zur Lagerpolitik (Berlin, 1998), pp. 268-269, and Dok. 64, pp. 276-277; Ralf Possekel, "Einleitung”, in ibid., p. 76.

55. Prikaz ministerstva ugol'noi promyshlennosti vostochnykh raionov SSSR, I.2.1947 [Order of the Ministry for the Coal Industry of the Eastern Regions of the USSR], GAKO, f. R-456, op. 4, d. $43,1.40$, in Markdorf-Sergeeva and Bikmetov, Inostrannye voennoplennye, pp. I0I-102. 
authorities. In particular, a POW who failed to report an escape attempt would be putting himself in danger. ${ }^{56}$

The relationship to the surrounding population was fraught and multi-layered. On the one hand, every family had its own victims of the war to bemoan. Those who had been evacuated from the European part of Russia to Siberia, or even from besieged Leningrad, faced the Germans with open hatred. On the other hand, postwar Soviet propaganda depicted the German people generally as having suffered under Nazism and thus having been victims of "financial capitalism". Although marriages between Soviet citizens and foreigners were forbidden by state law in 1947, there were secret affectionate relationships and extramarital affairs between POWs and Soviet women. Having a child born out of such a relationship could result in being relocated elsewhere and in social isolation, as one female miner remembers:

In the shaft worked a young and handsome guy, Johann. We made friends. $\mathrm{He}$ spoke Russian very badly, but we understood each other anyway. He tried to help me. One day he asked me to marry him. I was frightened and refused. If you had a relationship with a prisoner of war, no one would hug you. If one of us women had an affair with a German, she would hide it. There were rumours that one worker had a child with a POW. It was spoken about secretly, even the name was mentioned and after the birth of the child she did not return to the mine. No one knew what had happened to her; maybe she moved somewhere else or ended up in the places "not so far away" [i.e. the Gulag camps].57

Incidents against POWs could be reported and charges were heard in a military court. These processes reveal the improved status of the foreign POWs and internees. For example, an electric welder at the Anzherougol mines was convicted for taking the work gloves from an interned German female worker, another for beating a German POW. ${ }^{58}$ While most of the German and Japanese POWs were repatriated between I948 and I949, convicted POWs and many, often very young persons, who had been arrested and convicted in the Soviet Occupation Zone were held in Gulag-administered penal camps for many years to come.

\section{CONCLUSION}

In spite of the official egalitarian propaganda, the Kuzbass before World War II was a strictly hierarchic society. One's position in this hierarchy was marked by access to scarce goods. "Foreign specialists" were privileged and

56. Markdorf-Sergeeva and Bikmetov, Soderzhanie i trudovoe ispol'zovanie, p. 48.

57. Valentina Ivanova Petrova [family name changed], "Vospominaniia" [Memories], in Markdorf-Sergeeva and Bikmetov, Inostrannye voennoplennye, p. I 37.

58. Markdorf-Sergeeva and Bikmetov, Soderzhanie i trudovoe ispol'zovanie, p. 52. 
supplied with better housing and alimentation, while "special settlers" forced labourers mostly from European parts of the Soviet Union - were malnourished, left on their own, and discriminated against by the secret police.

This situation caused growing unrest. Extremely dangerous working conditions underground and a sudden rise in the number of accidents intensified these smouldering latent conflicts - which were seemingly "relieved" through the repressive campaigns of the authorities. With arbitrary arrests and executions of tens of thousands of people, always in the context of a presumed Fifth Column, society was kept in a state of permanent mobilization.

While the war itself saw the arrival of POWs in the Kuzbass coalfield, it was most notably after the war that the former enemy was put to work in the Kuzbass mines. About 30,000 POWs and internees from Germany, Japan, Austria, Hungary, and Romania were forced to work in the Kuzbass mines and on nearby construction sites. In the devastated country, especially during the hunger crisis of $1946-1947$, the POWs were poorly provided for, and soon only one-half of them were able to work any longer. As the economy needed a steady supply of coal, which necessitated a more efficient use of the labour force available, living conditions improved and POWs - especially those working underground in the mines - were given higher food rations and rewarded for meeting production targets. Although the POWs were supposed to work and live away from the local population, contacts and relationships at work or in the surroundings of the camps were frequent.

There is thus a long history of foreigners working in the Kuzbass coalfields, from the I920s until I950. This created both shared experiences and fraught relationships with other workers - who themselves had migrated or been forced to migrate from other, often faraway parts of Russia. Social hierarchies and ethnic attributions were subject to constant shifts and resulted in a series of peculiar constellations: whereas foreign specialists were comparatively privileged, both they and forced internal migrants (often with nationalities considered equally "foreign") were seen as possibly disloyal and suspicious once the Great Terror had begun. After the war, foreigners were recruited as prisoners of war and had to endure many hardships. In a country devastated and depopulated after the German assault, however, this workforce was desperately needed, and so, in the end, their status improved substantially. 